\title{
Enhanced growth and recombinant protein production of Escherichia coli by a perfluorinated oxygen carrier in miniaturized fed-batch cultures
}

\author{
Maciej Pilarek', Julia Glazyrina ${ }^{2}$ and Peter Neubauer ${ }^{2 *}$
}

\begin{abstract}
Background: Liquid perfluorochemicals (PFCS) are interesting oxygen carriers in medicine and biotechnology with a high solubility for oxygen. They have been repeatedly used for improving oxygen transfer into prokaryotic and eukaryotic cell cultures, however their application is still limited. Here we show the great benefit of air/oxygen saturated perfluorodecalin (PFD) for high cell density cultivation of Escherichia coli in microwell plates and their positive effect on the soluble production of a correctly folded heterologously expressed alcohol dehydrogenase.

Results: In EnBase ${ }^{\circledR}$ cultivations the best effect was seen with PFD saturated with oxygen enriched air (appr. 10 $\mu \mathrm{M}$ oxygen per $\mathrm{ml}$ ) when PFD was added at the time of induction. In contrast the effect of PFD was negligible when it was added already at the time of inoculation. Optimisation of addition time and content of loaded oxygen into the PFD resulted in an increased the cell density by $40 \%$ compared to control cultures, and correspondingly also the product yield increased, demonstrated at the example of a recombinant alcohol dehydrogenase.

Conclusions: PFCs are a valuable additive in miniaturized cell culture formats. For production of recombinant proteins in low cell density shaken cultures the addition of oxygen-enriched PFD makes the process more robust, i. e. a high product yield is not any more limited to a very narrow cell density window during which the induction has to be done. The positive effect of PFD was even more obvious when it was added during high cell density cultures. The effect of the PFD phase depends on the amount of oxygen which is loaded into the PFD and which thus is a matter of optimisation.
\end{abstract}

\section{Background}

Perfluorochemicals (PFCs), also known as fluorocarbons or perfluoroalkanes are synthetic fluorine-substituted derivatives of hydrocarbons, i.e. they are similar to hydrocarbons, but all hydrogens are replaced by fluoride. Due to the strength of the carbon-fluoride bond, they are stable and inert compounds with a high resistance to heat [1-3].

Liquid PFCs are characterized by a high solubility of oxygen, carbon dioxide and other non-polar gases which has raised much interest in medical and technical applications [3-5]. Perfluorinated liquids dissolve gases according to Henry's Law and the gas transfer rate into PFCs increases linearly with the partial pressure of a

\footnotetext{
* Correspondence: peter.neubauer@tu-berlin.de

2Laboratory of Bioprocess Engineering, Department of Biotechnology,

Technische Universität Berlin, Ackerstrasse 71-76, D-13355 Berlin, Germany

Full list of author information is available at the end of the article
}

component in the gaseous phase. There is no chemical attraction of oxygen molecules to PFCs in contrast with the sigmoid dissociation curve for biological oxygen carriers (e.g. hemoglobin or myoglobin). Molecules of gases are just occupying cavities between those of the liquid PFCs $[2,3,6]$. The lack of chemical bonds between oxygen and PFC also allows the easy release of oxygen, e.g. into a contacting water phase. The oxygen solubility in perfluorinated derivatives of hydrocarbons is 35 to $44 \mathrm{mM}$, which is approximately $20 \times$ higher than the solubility of oxygen in water $(2.2 \mathrm{mM})$. The solubility of carbon dioxide in liquid PFCs can even be up to $3 \times$ higher $[2,3]$.

For medical applications PFC emulsions have been studied as temporary intravascular oxygenation media (so-called "blood substitutes") and as media for preservation of human organs prior to transplantation. Pure liquid PFCs have been evaluated in liquid ventilation studies on premature and new born babies $[4,5,7]$.
C Biomed Central 
In experimental biotechnology various liquid PFCs were applied as carriers of different kinds of gases $\left(\mathrm{O}_{2}, \mathrm{CO}_{2}\right.$, $\mathrm{N}_{2} \mathrm{O}$ ) to supplying them into culture media or as scavengers of gaseous cellular by-products $[1-3,6]$. Other biotechnological applications of PFCs are related to culturing of 3-D animal cells aggregates on flexible liquid/ liquid interfacial created between PFC and culture medium layers $[8,9]$.

The use of PFCs as oxygen carriers in biotechnology has some advantages in comparison with other kinds of oxygen vectors such as chemically modified hemoglobin derivatives, siloxylated copolymers, silicone oils, or hydrocarbons. The lack of toxicity and no negative side-effects of liquid PFCs on various kinds of living cells were confirmed by experimental results and clinical researches [1-3,5]. Liquid PFCs are non-miscible with aqueous media and thus create a separate phase below the aqueous phase which can be effectively recovered from culture systems and then reused. Other merits of perfluorinated oxygen carriers is their heat stability, so that they can be autoclaved and their high chemical stability. Thus they can be stored easily at room temperature.

During the past thirty years many studies have shown that application of a perfluorinated oxygen carrier can facilitate oxygen transport in different types of microbial $[1-3,6,10]$, plant cell $[2,10]$ and animal cell cultures $[8,9]$, however so far this has not resulted in real applications. The reasons are that either the real improvements on growth were minor and especially the relatively high costs of PFCs.

There are only few studies in which PFCs were applied in Escherichia coli cultures. About six-fold higher cell densities of $E$. coli were obtained in bioreactor cultures which were periodically aerated by pure perfluoromethylodecalin sprayed into the culture medium and no adverse effects were observed [11]. In another study $E$. coli cells were cultivated in the presence of perfluorotributylamine in emulsified form. The emulsion with 20-50 $\mu \mathrm{m}$ droplets was obtained by intensive mechanical agitation within a bioreactor and the created emulsion was bubble aerated [12]. In this case the cell density increased only by a factor of two.

Biotechnological applications of PFCs are still limited by their relatively high cost, which makes their use in large-scale bioprocesses uneconomically. However, PFCs could be successfully used in miniature-scale cultivations of microbial cells to prevent oxygen limitation during grow to high cell densities, especially in high throughput screening approaches.

High cell density cultures are mostly performed as carbon source limited fed-batch by continuous addition of the carbon source as a highly concentrated liquid at a growth limiting rate. Importantly, to keep the culture in an aerobic state, the feed rate must be balanced with the volumetric oxygen transfer rate, which is limited by the poor solubility of oxygen into the aqueous medium and the technical setup, i.e. the sparging or shaking system. Furthermore, the feed rate has a direct influence on the final cell density. Consequently, approaches that increase the volumetric oxygen transfer rate allow a higher substrate feed rate and can thus result in higher cell densities.

The EnBase ${ }^{\circledR}$ technology is a miniaturized fed-batch cultivation system for high cell density cultivation of microorganisms [13-16]. In this system the controlled supply of glucose is realized by the use of an internally dissolved glucose polymer which cannot be directly assimilated by growing cells and the application of an amylolytic enzyme which releases single glucose monomers. The amount of the enzyme determines the release rate of glucose. By this simple principle EnBase allows the cultivation of cells under glucose-limited fed-batch conditions while the glucose feed rate, and thus the growth rate of the cells, can be simply controlled by the amount of the enzyme. However, the maximum amount of enzyme which can be added depends from the oxygen transfer rate.

Thus our hypothesis for this study was that air $/ \mathrm{O}_{2}$ saturated liquid PFCs can enhance the cell density and eventually production of recombinant proteins in smallscale high cell density cultivations, and this was tested in 24-deep well plates. The study was performed at the example for $E$. coli for the reason that this organism is widely used and E. coli small-scale cultures are widely applied e.g. in the metagenomic area, in high throughput crystallization of proteins, and for creation and screening of gene libraries.

To our knowledge this is the first report of the use of a perfluorinated oxygen carrier in a miniaturized fedbatch system to enhance the yield of cultured cells and protein production and probably also the first report on the application of air $/ \mathrm{O}_{2}$ saturated PFCs in high cell density bacterial cell cultures in general.

\section{Results}

Firstly, it was our aim to evaluate whether perfluorodecalin (PFD) has an effect on the growth of $E$. coli and production of a heterologous alcohol dehydrogenase $(\mathrm{ADH})$ in complex medium (LB) cultures performed in 24-deepwell plates (DWPs). Therefore E. coli RB791 pAdh was grown in DWPs at $30^{\circ} \mathrm{C}$. Half of the cultures were cultivated with a bottom phase of PFD which was saturated with oxygen-enriched air $\left(+40 \% \mathrm{v} / \mathrm{v} \mathrm{O}_{2}\right)$; the other cultures were performed without PFD (as control). All wells of the plate were inoculated at the same time, but different wells were induced at three different time points, representing different cell densities $\left(\mathrm{OD}_{600}\right.$ between 0.4 and 1.2), as we suggested that the effect of 
PFD might be dependent on the cell density. Although we could not detect any negative effects of PFD on the development of cell density, also no positive effects could be observed as it is shown in Figure 1.

The effect of the different culture conditions on product formation was evaluated by analysing the ADH accumulation in the soluble (correctly folded) or insoluble (inclusion bodies) protein fractions by SDSPAGE at the end of each experiment ( 9 hours after induction). Generally, high expression of $\mathrm{ADH}$ was observed in all samples. However, whereas the amount of the insoluble protein fraction was almost the same in all samples harvested from 24-DWP cultures on complex medium (LB), clear differences were observed for

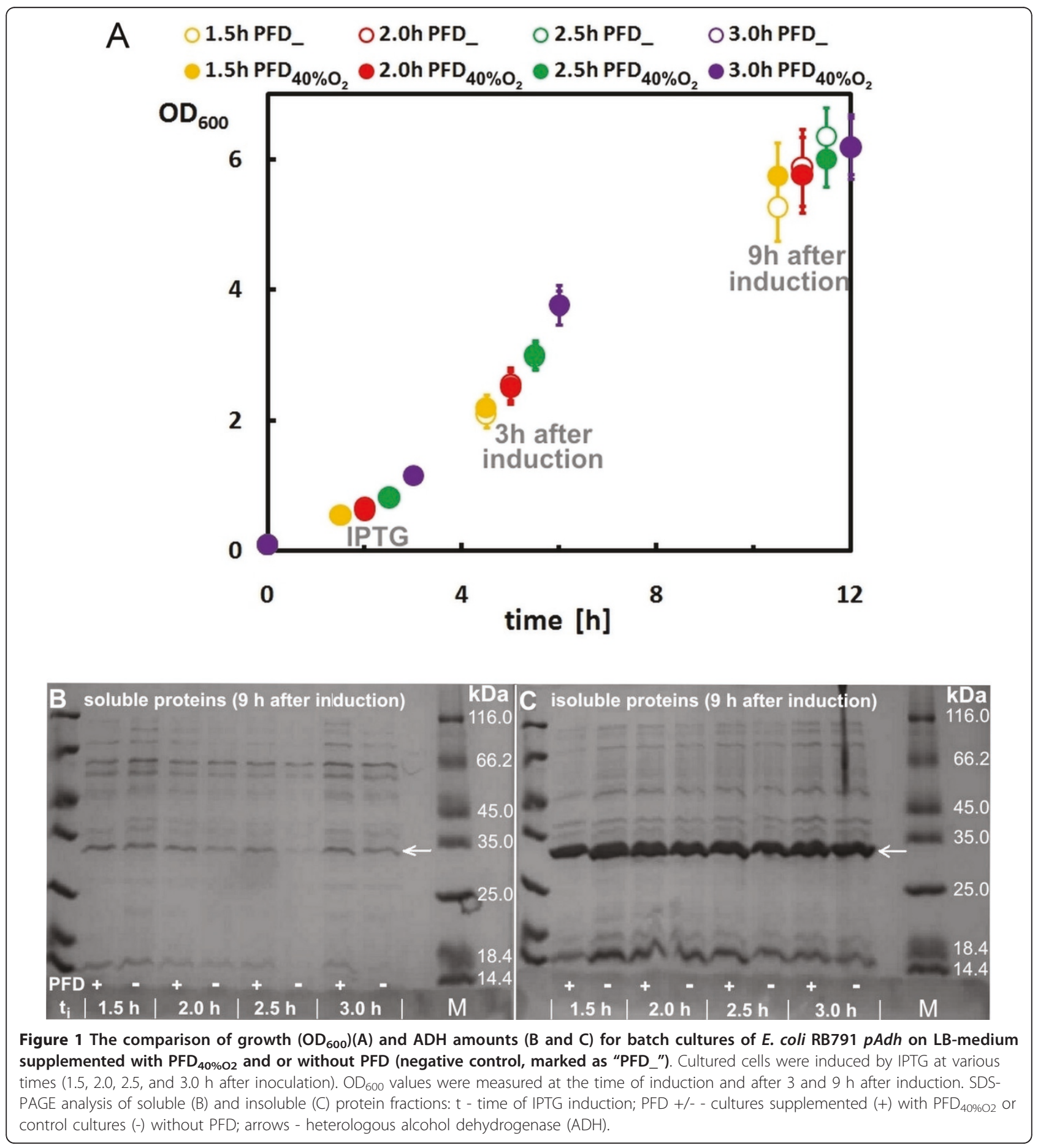


the amount of soluble ADH, which was especially improved in the PFD containing cultures which were induced at 2.0 or $2.5 \mathrm{~h}$ (cf. Figures $1 \mathrm{~B}$ and $1 \mathrm{C}$ ).

PFD in miniaturized fed-batch cultures of $E$. coli

Next experiments were performed as EnBase-Flo miniaturized fed-batch cultures in 24-DWPs. Initial experiments showed that the cell density was not affected when PFD was added from the start of the cultivation, but there was an improved benefit when PFD was added later during the cultivation at higher cell densities (data not shown). Thus we decided to add PFD only after 15 hours of cultivation, to provide the proposed beneficial effect only when the culture's metabolism is activated by addition of the EnBase booster mix and additionally 1.5 GAU $L^{-1}$ of polymer degrading enzyme, which has been earlier shown to be beneficial for the $\mathrm{pH}$ balance and thus resulted in a higher yield of a number of recombinant proteins (see [13]).

In our case, as typical for EnBase cultures all wells reached approximately the same $\mathrm{OD}_{600}$ of approximately 10 during the initial 15 hours, i.e. the time of induction and PFD addition (Figure 2).

After addition of the PFD phase, booster mix and additional enzyme we observed a clear effect of PFD on the further growth, dependent on the added enzyme concentration. Without PFD in all instances the final $\mathrm{OD}_{600}$ was significantly lower compared to cultures with PFD. The highest cell concentrations in the PFC containing cultures with a final concentration of glucoamylase in the range of 1.5 to $4.5 \mathrm{U} \mathrm{L}^{-1}$ were about $40 \%$ higher compared to the cultures which were not supplied with PFD. The highest
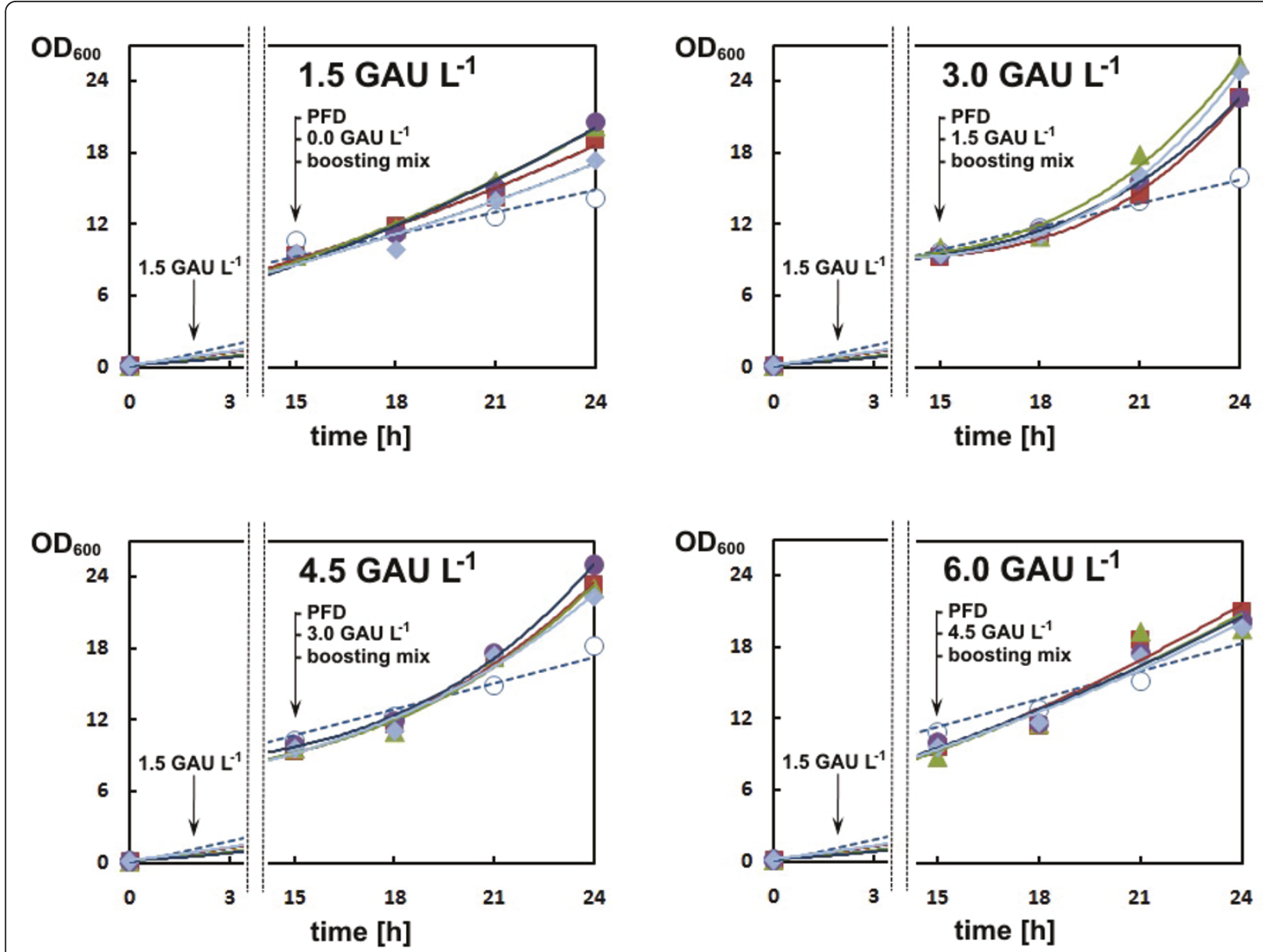

\section{PFD_ PFD $_{\text {air }} \triangle \mathrm{PFD}_{20 \% \mathrm{O}_{2}} \bigcirc \mathrm{PFD}_{40 \% \mathrm{O}_{2}} \diamond \mathrm{PFD}_{\mathrm{O}_{2}}$}

Figure 2 Growth curves of E. coli RB791 pAdh cells cultured in EnBase-Flo and supplementation with PFD loaded with different concentrations of $\mathrm{O}_{2}$ at the time of induction. The control culture without PFD is named "PFD_". 
cell density was obtained in the presence of PFD enriched with $40 \% \mathrm{v} / \mathrm{v}$ of pure oxygen at a concentration of $4.5 \mathrm{U} \mathrm{L}^{-}$ ${ }^{1}$ of glucoamylase. The $\mathrm{OD}_{600}$ values of the cultures supplemented with PFC saturated with pure oxygen were higher than those measured for control cultures, but significantly lower than the densities which were obtained with a perfluorinated phase which was enriched with $40 \%$ v/v of pure $\mathrm{O}_{2}$ (cf. Figure 2). All cultures produced the model protein $\mathrm{ADH}$ in high concentration. The amount of soluble product per cell was the same in all cultures, independent on the amount of PFD (shown exemplary for the cultures with 1.5, 3.0, and 4.5 units of amylase for PFD saturated with air or $60 \% \mathrm{v} / \mathrm{v}$ of oxygen in Figure 3) and thus, the final volumetric product yield was highest in the cultures which also showed the highest cell density according to Figure 3.

\section{Discussion}

PFC supplementation of microbial cultures has been in the past applied to improve the oxygen transfer [2-4]. However, the application of PFCs was mainly limited to its relatively high price and the relatively small effect on fermentations, where other alternatives for increasing the oxygen transfer exist.

Recently there are many activities to apply fed-batch technologies under miniaturised culture conditions [17-20], as process development can be significantly shortened by applying already at this scale conditions which are typical for the industrial processes [21]. In contrast to the bioreactor scale, where $k_{L} a$ values are relatively high and additionally oxygen can be supplied to the gas phase, oxygen limitation is a major bottleneck in micro-scale cultures. Especially microwell and

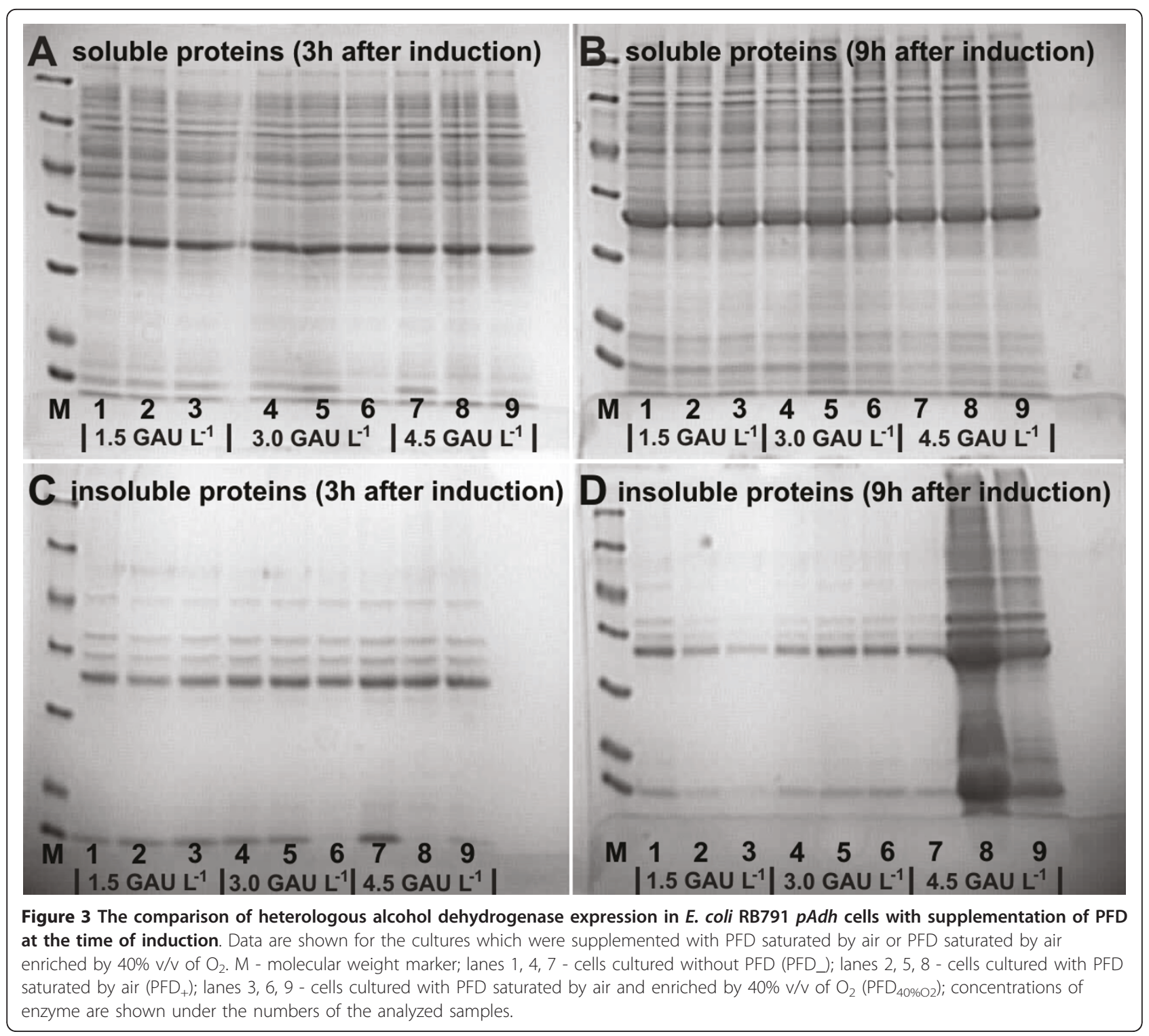


deepwell plates have lower $k_{L} a$ values [22,23], and under these conditions also the price for the application of PFCs is not any more a limitation due to the small volumes which are needed. Thus it was a major aim in the actual study to investigate which benefit is possible by the use of PFC's in ml-scale cultures.

Our results show that in deepwell plate cultures PFD can provide a severe growth benefit and even can improve the yield of correctly folded product. For this however, PFCs should be not applied at the early culture phase, as under these conditions the oxygen would be delivered already during a time where oxygen diffusion from air is not limiting the culture growth. Over the long time of cultivation the excess oxygen from the carrier can diffuse into the culture medium and finally to the air phase and thus the oxygen-enriched PFD is not effective. But, we could show that PFD addition is very beneficial after a high cell density has been reached at the time of induction, when it is also known that the cells have a high respiration requirement [24]. Under these conditions the biomass yield could be increased by $40 \%$ and thus the volumetric yield of soluble ADH also increased (cf. Figure 3).

A major point which was newly addressed in this paper compared to other fermentation studies where this had been overlooked was the concentration of oxygen in the PFD phase. Too high oxygen concentration resulted in growth inhibition. In the tests performed here an optimum was found where the PFD is enriched by $40 \% \mathrm{v} / \mathrm{v}$ of pure $\mathrm{O}_{2}$. High $\mathrm{pO}_{2}$ levels in the culture medium could provoke the increase of $\mathrm{H}_{2} \mathrm{O}_{2}$ or oxygen radicals, and consequently may lead to oxidative stress and membrane damage $[25,26]$. The inhibitory effect of concentrated oxygen has been observed previously for plant cells cultured in the presence of oxygen loaded PFD [10].

It is generally considered in batch cultures, that the cell density of induction in shaken cultures is a very critical parameter for protein production. Slight changes in the time of induction, i.e. cell density, have big effects. Thus it was surprising, that in the case of added PFD, good accumulation of ADH was obtained in all cultures, i.e. in this case the time of induction was not any more a critical parameter and thus cultures were much more robust. This is similar to fermentation processes, where with a good supply of medium components and the control of the culture growth rate by the carbon source, i.e. application of the substrate limited fed-batch strategy, the process is very robust in connection to the induction cell density (see e.g. [21]).

High expression of heterologous ADH encoded by the $p A d h$ plasmid has been observed in all cultures supplemented with or without PFD-based oxygen carrier. However, it is remarkable that the amount of ADH in the insoluble protein fraction was lower in the cultures with $1.5 \mathrm{GAU} \mathrm{L}^{-1}$ additionally added enzyme with high amount of loaded oxygen to PFD. This may be due to the higher turnover of inclusion bodies as earlier described e.g. for $\alpha$-glucosidase [27], which is dependent on ATP. This observation is interesting and will be further investigated.

\section{Conclusions}

The results of our experiments have confirmed the feasibility and benefit of perfluorinated oxygen carrier application in high cell density cultures of $E$. coli at the example of miniaturised cultivation systems. Supplementation of the miniaturized fed-batch system (as EnBaseFlo) with aerated/oxygenated PFD had positive effects on E. coli RB791 pAdh cells cultivated to reasonable high cell density. The oxygen containing PFC phase enhanced the growth of $E$. coli cells and higher $\mathrm{OD}_{600}$ values were measured in cultures supplemented with this oxygenated liquid oxygen carrier compared to control cultures without any PFD added. The highest value of cell density has been noted when cultures were supplemented with PFD saturated by air and mixed in a 60/ $40 \% \mathrm{v} / \mathrm{v}$ ratio with $\mathrm{O}_{2}$ saturated PFD. Interestingly the improved oxygen supply did not only increase the cell density, but also resulted in a higher volumetric yield of the target protein.

Our results indicate that PFD-based oxygenation systems may be valuable additives in miniaturized cell culture formats. The positive effect of PFD is even more obvious when is added during high cell density cultures and the effect depends on the amount of oxygen loaded to the PFD.

\section{Methods}

\section{Bacterial strain}

The recombinant strain of Escherischia coli RB791 pAdh [28] encoding a heterologous alcohol dehydrogenase was used in this work. The gene of an alcohol dehydrogenase (adh) from Lactobacillus spec. was cloned into the pQE30 plasmid (Qiagen, USA) yielding the vector $\mathrm{pQE30adh}$ and the protein was expressed in E. coli RB791 [F- IN( $r r n D-r r n E 1), \lambda^{-}$, lacI $^{q} L_{8}$ ] kindly provided by the E. coli Genetic Stock Center (New Haven, USA).

\section{Cultivation media}

Two different media were used for the cultivations: (1) EnBase-Flo Mineral Salt Medium (MSM) and (2) EnBase-Flo Complex Medium (CM). Both of them were obtained from BioSilta Oy (Oulu, Finland) and have been earlier introduced by Krause et al. [13]. The MSM and $\mathrm{CM}$ had the following composition: $\mathrm{Na}_{2} \mathrm{SO}_{4}(2.0 \mathrm{~g}$ $\left.\mathrm{L}^{-1}\right),\left(\mathrm{NH}_{4}\right)_{2} \mathrm{SO}_{4}\left(6.12 \mathrm{~g} \mathrm{~L}^{-1}\right), \mathrm{NH}_{4} \mathrm{Cl}\left(0.50 \mathrm{~g} \mathrm{~L}^{-1}\right)$, $\mathrm{K}_{2} \mathrm{HPO}_{4}\left(14.60 \mathrm{~g} \mathrm{~L}^{-1}\right), \mathrm{NaH}_{2} \mathrm{PO}_{4} \cdot \mathrm{H}_{2} \mathrm{O}\left(3.60 \mathrm{~g} \mathrm{~L}^{-1}\right)$, 
$\left(\mathrm{NH}_{4}\right)_{2}$ - $\mathrm{H}$-citrate $\left(1.00 \mathrm{~g} \mathrm{~L}^{-1}\right), \mathrm{MgSO}_{4}(3 \mathrm{mM})$, thiamine hydrochloride $\left(0.1 \mathrm{~g} \mathrm{~L}^{-1}\right)$ and $2 \mathrm{ml}$ trace element solution (containing per litre: $0.50 \mathrm{~g} \mathrm{CaCl}_{2} \cdot 2 \mathrm{H}_{2} \mathrm{O}, 0.18 \mathrm{~g}$ $\mathrm{ZnSO}_{4} \cdot 7 \mathrm{H}_{2} \mathrm{O}, 0.10 \mathrm{~g} \mathrm{MnSO}_{4} \cdot \mathrm{H}_{2} \mathrm{O}, 20.1 \mathrm{~g} \mathrm{Na}_{2}$-EDTA, $16.70 \mathrm{~g} \mathrm{FeCl}_{3} \cdot 6 \mathrm{H}_{2} \mathrm{O}, 0.16 \mathrm{~g} \mathrm{CuSO}_{4} \cdot 5 \mathrm{H}_{2} \mathrm{O}$ and $0.18 \mathrm{~g}$ $\mathrm{CoCl}_{2} \cdot 6 \mathrm{H}_{2} \mathrm{O}$ ). Both used media differed in level of organic nitrogen compounds and were further supplemented with complex medium additives (optimized combination of peptones and yeast extracts) commercially named as EnBase Boosting mix (BioSilta Oy): CM had a 10 times higher concentration of complex additives then MSM.

The LB medium (10 $\mathrm{g} \mathrm{L}^{-1}$ Trypton, $5 \mathrm{~g} \mathrm{~L}^{-1}$ yeast extract and $5 \mathrm{~g} \mathrm{~L}^{-1} \mathrm{NaCl} ; \mathrm{pH}$ was set to 7.0 ) was used for inoculum preparation.

\section{Perfluorinated oxygen carrier}

Perfluorodecalin (PFD; $\mathrm{C}_{10} \mathrm{~F}_{18} ; 1,1,2,2,3,3,4,4 \mathrm{a}, 5,5,6$, 6,7,7,8,8,8a-octadecafluorodecalin, ABCR GmbH, Karlsruhe, Germany) was used as a liquid oxygen carrier in this work. According to the information of the supplier the applied PFD is a $98 \% \mathrm{~m} / \mathrm{m}$ equimolar mixture of (cis-/ trans-) isomers. The density of used liquid PFD is $1.941 \mathrm{~kg}$ $\mathrm{L}^{-1}$ (at $25^{\circ} \mathrm{C}$ ), dynamic viscosity is $5.1 \mathrm{mPa} \cdot \sec \left(\right.$ at $25^{\circ} \mathrm{C}$ ) and surface tension is 1.6 Pa. The used PFD did not disperse and remained at the bottom of wells during all experiments.

PFD was sterilized by autoclaving, cooled to $37^{\circ} \mathrm{C}$ and then PFD was saturated by compressed air and pure oxygen in aseptic conditions supplied with a $0.2 \mu \mathrm{m}$ cartridge filter to prevent microbial contamination [10]. It is known that oxygen solubility in PFD does not vary significantly with temperature [29]. $4.0 \mathrm{mM} \mathrm{O}_{2}\left(0.128 \mathrm{~g} \mathrm{O}_{2}\right)$ from air [30] or $19.2 \mathrm{mM} \mathrm{O}_{2}\left(0.614 \mathrm{~g} \mathrm{O}_{2}\right)$ from pure oxygen can be dissolved in $1 \mathrm{~L}$ of PFD at $37^{\circ} \mathrm{C}$ [29]. Different kinds of PFD mixtures were used during the experiments and the calculated values of oxygen concentration in used PFD mixtures are presented in Table 1.

Unsaturated perfluorodecalin $\left(\mathrm{PFD}_{+}\right)$was also used in reference experiments to evaluate possible side effects triggered by the perfluorochemical. The culture which was not supplemented with PFD (marked as PFD_) was also used as reference. PFD created a separate phase on the bottom of the wells after pipetting as it cannot mix with aqueous systems. Thus, the volume of PFD which was added to the culture medium does not change the concentration of its ingredients.

\section{Cultivation}

The E. coli RB791 pAdh inoculum was prepared from a overnight Petri dish culture with LB agar at $30^{\circ} \mathrm{C}$. Precultures were washed from the plate with $3.0 \mathrm{ml}$ of fresh MSM and after $\mathrm{OD}_{600}$ measurement the suspension of E. coli cells was used as inoculum. All cultures were started with an $\mathrm{OD}_{600}$ of 0.15 .

Cultivations of E. coli RB791 pAdh were performed in square-bottom 24-deep-well plates (DWP). The initially culture volume was $2.5 \mathrm{ml}$. The DWPs were covered with a gas-permeable membrane (Easy-Breath Self Adhesive Sheets; BioSilta $\mathrm{Oy}$ ) to provide aeration during cultivation. All cultures were incubated at $30^{\circ} \mathrm{C}$ on orbital shakers (250 rpm, 2.5 orbit, Kuhner) and cells were precultivated for 2 hours before the initial addition of $1.5 \mathrm{U} \mathrm{L}^{-1}$ of glucoamylase (GA). Enzyme was not added immediately after inoculation in order to prevent the immediate release of glucose subunits from the carbohydrate polymer.

After 15 hours of cultivation the cultures were induced with $1 \mathrm{mM}$ of isopropyl $\beta$-D-1-thiogalactopyranoside (IPTG; Carl Roth GmbH, Karlsruhe, Germany). At the same time the cultures were supplemented with $0.6 \mathrm{ml}$ of EnBase Boosting Mix as recommended by the supplier (BioSilta), and simultaneously also $3.0 \mathrm{ml}$ gassaturated PFD was added to the cultures and additional amounts of GA as indicted in the Results section to obtain final concentrations of the amylolytic enzyme of 1.5, 3.0, 4.5, and $6.0 \mathrm{U} \mathrm{L}^{-1}$.

$100 \mu \mathrm{l}$ samples were harvested to measure the $\mathrm{OD}_{600}$ and eventually for SDS-PAGE analysis of soluble and insoluble proteins. The average rate of water evaporation from the cultures through the air permeable membrane was calculated as $9.1 \mu \mathrm{h}^{-1}$ for every used well of DWP. All experiments were performed twice and the shown $\mathrm{OD}_{600}$ values are an average of the measured values of the single cultures.

Table 1 Mixtures of PFD used during experiments and total content of oxygen in the liquid oxygen carrier

\begin{tabular}{|c|c|c|c|c|}
\hline \multirow[t]{2}{*}{ Symbol } & \multirow[t]{2}{*}{ Composition of PFD mixture (per $1.0 \mathrm{ml}$ ) } & \multicolumn{3}{|c|}{ Content of oxygen $\left[\mu \mathrm{M} \mathrm{O}_{2}\left(\mathrm{ml}^{-1} \mathrm{PFD}\right)\right]$} \\
\hline & & from air & from pure oxygen & total \\
\hline PFD $_{\text {air }}$ & $1.0 \mathrm{ml}$ PFD $_{\text {air }}$ & 4.00 & 0 & 4.00 \\
\hline $\mathrm{PFD}_{20 \% 02}$ & $0.8 \mathrm{ml} \mathrm{PFD}$ air $+0.2 \mathrm{ml} \mathrm{PFD} \mathrm{O}_{2}$ & 3.20 & 3.84 & 7.04 \\
\hline $\mathrm{PFD}_{40 \% 02}$ & $0.6 \mathrm{ml} \mathrm{PFD}$ air $+0.4 \mathrm{ml} \mathrm{PFD} \mathrm{O}_{2}$ & 2.40 & 7.68 & 10.08 \\
\hline $\mathrm{PFD}_{60 \% 02}$ & $0.4 \mathrm{ml} \mathrm{PFD}$ air $+0.6 \mathrm{ml} \mathrm{PFD} \mathrm{O}_{2}$ & 1.60 & 11.52 & 13.12 \\
\hline $\mathrm{PFD}_{80 \% 02}$ & $0.2 \mathrm{ml} \mathrm{PFD}$ air $+0.8 \mathrm{ml} \mathrm{PFD} \mathrm{O}_{2}$ & 0.80 & 15.36 & 16.16 \\
\hline $\mathrm{PFD}_{\mathrm{O} 2}$ & $1.0 \mathrm{ml} \mathrm{PFD}_{\mathrm{O} 2}$ & 0 & 19.20 & 19.20 \\
\hline
\end{tabular}

The oxygen concentration in PFD was calculated based on data published by Costa Gomez et al. [29] and Amaral et al. [31]. 


\section{Analytical methods}

Cell growth was followed with a spectrophotometer after the dilution of harvested culture samples in culture medium at $600 \mathrm{~nm}\left(\mathrm{OD}_{600}\right)$. All cell density values are presented as $\mathrm{OD}_{600}$ values. For non-induced cells the $\mathrm{OD}_{600}$ value of 1 is equivalent to $1.7 \mathrm{~g} \mathrm{~L}^{-1}$ of wet cell weight and to $0.39 \mathrm{~g} \mathrm{~L}^{-1}$ of dry cell weight of E. coli RB791 pAdh biomass. This relation slightly changes after induction.

\section{Protein analysis}

Samples for protein analysis were harvested at $9 \mathrm{~h}$ after IPTG addition. All samples were standardized to equal $\mathrm{OD}_{600}$ values of 10 . Therefore, protein productivity per cell in different samples can be directly compared on the basis of the protein band thickness. Standardized samples were pelleted by centrifugation $\left(13,000 \times \mathrm{g}, 5 \mathrm{~min}, 4^{\circ} \mathrm{C}\right)$, supernatants were discarded and the pellets were frozen at $-20^{\circ} \mathrm{C}$. For analysis, each cell pellet was resuspended in 1.0 $\mathrm{ml} 0.1 \mathrm{M}$ Tris/ $\mathrm{HCl}$ in $1.0 \mathrm{mM}$ EDTA buffer ( $\mathrm{pH} 7.0$ ) and $2.0 \mu \mathrm{l}$ of lysozyme $\left(50 \mathrm{mg} \mathrm{mL}^{-1}\right.$ ) was added. After incubation on ice for $30 \mathrm{~min}$, the resuspended pellets were disrupted by sonication on ice (UPS200, sonotrode with $2 \mathrm{~mm}$ diameter, $70 \%$ power input, Dr. Hielscher GmbH, Germany) in $3 \times 30 \mathrm{sec}$ periods with $45 \mathrm{sec}$ cooling breaks in between. To obtain the soluble and insoluble protein fractions, the disrupted cell solution was centrifuged $\left(13,000 \times \mathrm{g}, 5 \mathrm{~min}, 4^{\circ} \mathrm{C}\right)$ and an aliquot for the soluble protein analysis was drawn from the supernatant. The pellet was also harvested for analysis of the insoluble protein fraction. The supernatant was directly used as soluble protein sample. The pellets of the insoluble protein fraction were suspended in $1.0 \mathrm{ml}$ of $0.1 \mathrm{M}$ Tris/ $\mathrm{HCl}$ in $1.0 \mathrm{mM}$ EDTA buffer ( $\mathrm{pH}$ 7.0) before analysis. The soluble and insoluble fractions were analyzed by SDS-PAGE on $12 \%$ $\mathrm{m} / \mathrm{m}$ polyacrylamide gels $(60 \mathrm{~V}$ for $30 \mathrm{~min}$ followed by 90 $\mathrm{V}$ for $90 \mathrm{~min}$ ). The bands were visualized by Comassie Brillant Blue R 250 solution according to standard staining method modified by Besir's [30].

\footnotetext{
Acknowledgements

Authors kindly acknowledge the supply of culture media by BioSilta Oy (Oulu, Finland).

Work of MP at the TU Berlin was supported by the European Social Fund of the European Union through the Warsaw University of Technology Development Programme (CAS/4/POKL).
}

\section{Author details}

'Department of Biotechnology and Bioprocess Engineering, Faculty of Chemical and Process Engineering, Warsaw University of Technology, Warynskiego 1, 00-645 Warsaw, Poland. ' Laboratory of Bioprocess Engineering, Department of Biotechnology, Technische Universität Berlin, Ackerstrasse 71-76, D-13355 Berlin, Germany.

\section{Authors' contributions}

MP carried out most of the experiments, did the analyses and drafted the manuscript. JG participated in the experiments with the DWPs. PN supervised the study, and participated in its design and coordination, helped to draft and writing of the manuscript. All authors read and approved the final manuscript.

\section{Competing interests}

MP and JG declare that they have no competing interests. PN is an adviser to Biosilta Oy.

Received: 15 February 2011 Accepted: 27 June 2011

Published: 27 June 2011

\section{References}

1. Mattiasson B, Adlercreutz P: Perfluorochemicals in biotechnology. Trends in Biotechnol 1987, 5:250-254

2. Lowe KC: Perfluorochemical respiratory gas carriers: benefits to cell culture systems. J Fluorine Chem 2002, 118:19-26.

3. Riess JG: Perfluorocarbon-based Oxygen Delivery. Artificial Cells, Blood Substitutes and Biotechnol 2006, 34:567-580.

4. Lowe KC: Fluorinated blood substitutes and oxygen carriers. J Fluorine Chem 2001, 109:59-65.

5. Krafft MP: Fluorocarbons and fluorinated amphiphiles in drug delivery and biomedical research. Adv Drug Deliv Rev 2001, 47:209-228.

6. King AT, Mulligan BJ, Lowe KC: Perfluorochemicals and cell culture. Biotechnology 1989, 7:1037-1042.

7. Riess JG: Oxygen carriers ('Blood substitutes') - Raison d'Etre, chemistry, and some physiology. Chemical Reviews 2001, 101:2797-2919.

8. Shiba Y, Ohshima T, Sato M: Growth and morphology of anchoragedependent animal cells in a liquid/liquid interface system. Biotechnol Bioeng 1998, 57:583-589.

9. Rappaport C: Progress in concept and practice of growing anchoragedependent mammalian cells in three dimension. In Vitro Cell Dev Biol Anim 2003, 39:187-192.

10. Pilarek M, Szewczyk KW: Effects of perfluorinated oxygen carrier application in yeast, fungi and plant cell suspension cultures. Biochem Engin J 2008, 41:38-42.

11. Damiano D, Wang SS: Novel use of perfluorocarbon for supplying oxygen to aerobic submerged cultures. Biotechnol Lett 1985, 7:81-86.

12. Ju LK, Lee JF, Armiger WB: Enhancing oxygen transfer in bioreactors by perfluorocarbon emulsions. Biotechnol Progress 1991, 7:323-329.

13. Krause M, Ukkonen K, Haataja T, Ruottinen M, Glumoff T, Neubauer A, Neubauer P, Vasala A: A novel fed-batch based cultivation method provides high cell-density and improves yield of soluble recombinant proteins in shaken cultures. Microb Cell Fact 2010, 9:11.

14. Panula-Perälä J, Siurkus J, Vasala A, Wilmanowski R, Casteleijn MG, Neubauer P: Enzyme controlled glucose auto-delivery for high cell density cultivations in microplates and shake flasks. Microb Cell Fact 2008, 7:31.

15. Glazyrina J, Materne EM, Dreher T, Storm D, Junne S, Adams T, Greller G, Neubauer P: High cell density cultivation and recombinant protein production with Escherichia coli in a rocking-motion-type bioreactor. Microb Cell Fact 2010, 9:42.

16. Tegel H, Yderland L, Bostrom T, Eriksson C, Ukkonen K, Vasala A, Neubauer P, Ottosson J, Hober S: Parallel production and verification of protein products using a novel high-throughput screening method. Biotechnol J 2011.

17. Weuster-Botz D: Parallel reactor systems for bioprocess development. Adv Biochem Eng Biotechnol 2005, 92:125-143.

18. Betts Jl, Doig SD, Baganz F: Characterization and application of a miniature $10 \mathrm{~mL}$ stirred-tank bioreactor, showing scale-down equivalence with a conventional $7 \mathrm{~L}$ reactor. Biotechnol Progr 2006, 22:681-688.

19. Schapper D, Alam MNHZ, Szita N, Lantz AE, Gernaey KV: Application of microbioreactors in fermentation process development: a review. Anal Bioanal Chem 2009, 395:679-695.

20. Neubauer P, Junne S: Scale-down simulators for metabolic analysis of large-scale bioprocesses. Curr Opin Biotechnol 2010, 21:114-121.

21. Siurkus J, Panula-Perälä J, Horn U, Kraft M, Rimseliene R, Neubauer P: Novel approach of high cell density recombinant bioprocess development: optimisation and scale-up from microliter to pilot scales while maintaining the fed-batch cultivation mode of $E$. coli cultures. Microb Cell Fact 2010, 9:35. 
22. Hermann R, Lehmann M, Büchs J: Characterization of gas-liquid mass transfer phenomena in microtiter plates. Biotechnol Bioeng 2003, 81:178-186.

23. Kensy F, Zimmermann HF, Knabben I, Anderlei T, Trauthwein $\mathrm{H}$, Dingerdissen U, Büchs J: Oxygen transfer phenomena in 48-well microtiter plates: determination by optical monitoring of sulfite oxidation and verification by real-time measurement during microbial growth. Biotechnol Bioeng 2005, 89:698-708.

24. Neubauer P, Lin HY, Mathiszik B: Metabolic load of recombinant protein production: inhibition of cellular capacities for glucose uptake and respiration after induction of a heterologous gene in Escherichia coli. Biotechnol Bioeng 2003, 83:53-64.

25. Farr SB, Touati D, Kogoma T: Effects of oxygen stress on membrane functions in Escherichia coli: role of HPI catalase. J Bacteriol 1988, 170:1837-1842.

26. Dukan S, Nyström T: Oxidative stress defense and deterioration of growth-arrested Escherichia coli cells. J Biol Chem 1999, 274:26027-26032.

27. Le TH, Hoffmann F: Optimized production of active alpha-glucosidase by recombinant Escherichia coli. evaluation of processes using in vivo reactivation from inclusion bodies. Biotechnol Prog 2005, 21:1053-1061.

28. Viitanen MI, Vasala A, Neubauer P, Alatossava T: Cheese whey-induced high-cell-density production of recombinant proteins in Escherichia coli. Microb Cell Fact 2003, 2:2.

29. Costa Gomez MF, Deschamps J, Menz DH: Solubility of dioxygen in seven fluorinated liquids. J Fluorine Chem 2004, 125:1325-1329.

30. Besir H: Coomassie Staining without Alcohol and Acetic Acid. Lab Times 2008, 6:53.

31. Amaral PF, Freire MG, Rocha-Leao MH, Marrucho IM, Coutinho JA, Coelho MA: Optimization of oxygen mass transfer in a multiphase bioreactor with perfluorodecalin as a second liquid phase. Biotechnol Bioeng 2008, 99:588-598.

doi:10.1186/1475-2859-10-50

Cite this article as: Pilarek et al: Enhanced growth and recombinant protein production of Escherichia coli by a perfluorinated oxygen carrier in miniaturized fed-batch cultures. Microbial Cell Factories 2011 10:50.

\section{Submit your next manuscript to BioMed Central and take full advantage of:}

- Convenient online submission

- Thorough peer review

- No space constraints or color figure charges

- Immediate publication on acceptance

- Inclusion in PubMed, CAS, Scopus and Google Scholar

- Research which is freely available for redistribution

Submit your manuscript at www.biomedcentral.com/submit
Biomed Central 